\title{
Effectiveness of water infrastructure for river flood management - Part 1: Flood hazard assessment using hydrological models in Bangladesh
}

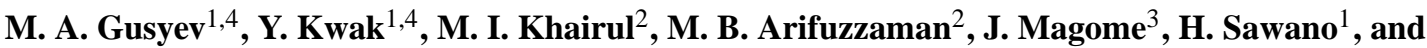 \\ K. Takeuchi ${ }^{1,4}$ \\ ${ }^{1}$ International Centre for Water Hazard and Risk Management (ICHARM) under the auspices of UNESCO, \\ Public Works Research Institute (PWRI), Tsukuba, Japan \\ ${ }^{2}$ Bangladesh Water Development Board, Dhaka, Bangladesh \\ ${ }^{3}$ International Research Center for River Basin Environment (ICRE), Interdisciplinary Graduate School of \\ Medicine and Engineering, University of Yamanashi, Kofu, Japan \\ ${ }^{4}$ National Graduate Institute for Policy Studies (GRIPS), Tokyo, Japan \\ Correspondence to: M. A. Gusyev (gusyev55@pwri.go.jp)
}

Received: 12 March 2015 - Accepted: 12 March 2015 - Published: 11 June 2015

\begin{abstract}
This study introduces a flood hazard assessment part of the global flood risk assessment (Part 2) conducted with a distributed hydrological Block-wise TOP (BTOP) model and a GIS-based Flood Inundation Depth (FID) model. In this study, the $20 \mathrm{~km}$ grid BTOP model was developed with globally available data on and applied for the Ganges, Brahmaputra and Meghna (GBM) river basin. The BTOP model was calibrated with observed river discharges in Bangladesh and was applied for climate change impact assessment to produce flood discharges at each BTOP cell under present and future climates. For Bangladesh, the cumulative flood inundation maps were produced using the FID model with the BTOP simulated flood discharges and allowed us to consider levee effectiveness for reduction of flood inundation. For the climate change impacts, the flood hazard increased both in flood discharge and inundation area for the 50- and 100-year floods. From these preliminary results, the proposed methodology can partly overcome the limitation of the data unavailability and produces flood maps that can be used for the nationwide flood risk assessment, which is presented in Part 2 of this study.
\end{abstract}

\section{Introduction}

Bangladesh is flood prone and densely populated country that is located at the confluence of the Ganges, Brahmaputra and Meghna (GBM) rivers (FAO, 2012). In Bangladesh, the frequent floods cause fatalities and economic losses and are due to the combined influence of these rivers. Among these floods, the 1998 flood affected 53 out of 64 districts in Bangladesh and was considered the most devastating flood (BWDB, 2014). Despite these frequent floods, embankments are only available means for the flood hazard reduction in Bangladesh while the forecasting of flood peaks in Bangladesh is complicated due to lack of hydrometeorological and water use data outside of Bangladesh. For example, a special version of MIKE11 Flood Fore- casting (FF) model simulates flood river discharges in Bangladesh by assuming fixed boundary river discharge at Bangladesh's border (BWDB, 2014). Therefore, the existing levee infrastructure in Bangladesh needs to be considered with GBM flood flows in the flood hazard assessment to investigate its effectiveness due to climate change impacts.

Up to date, a number of hydrological and inundation models have been utilized in the GBM basin and its subcatchments with limited local observed data (Johnston and Smakhtin, 2014; BWDB, 2014). Kwak et al. (2012) assessed flood inundation depth and area maps in Asia-Pacific region including the GBM river basin using GIS-based flood inundation depth (FID) model with flood peak discharges of the global $20 \mathrm{~km}$ BTOP model, which is distributed hydrological model calibrated at the Mekong River basin (Takeuchi et 


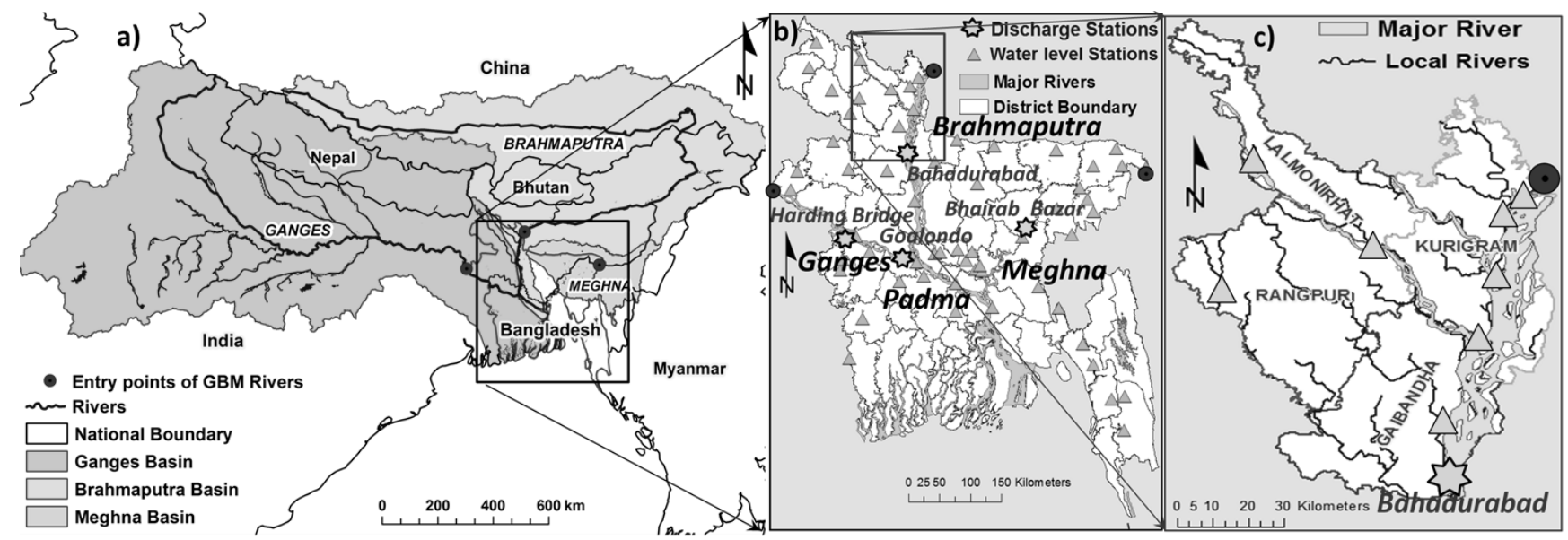

Figure 1. The Ganges, Brahmaputra and Meghna (GBM) river basin in Nepal, India, China, Bhutan and Bangladesh (a). The Bangladesh river water level and discharge gauging stations are demonstrated in zoom-in (b) and the Lalmonirhat, Kurigram, Gaibandha and Rangpur districts in zoom-in (c).

al., 2008). Winsemius et al. (2013) used $50 \mathrm{~km}$ hydrological model PCR-GLOBWB globally including the GBM basin to estimate flood discharge and flood inundation, but they also did not conduct model calibration with the observed river discharges. In addition, neither of the studies considers levee infrastructure for the flood inundation simulations. Recently, Masood et al. (2015) investigated the change of hydrologic variables with $10 \mathrm{~km}$ hydrologic model $\mathrm{H} 08$, which was applied for the GBM basin and calibrated to Bangladesh river discharge data. However, Masood et al. (2015) did not analyze the flood peak river discharges and did not conduct flood inundation simulations. Therefore, a calibrated hydrological model forced with globally available hydro-meteorological data, is useful to simulate Bangladesh flood river inflows and to investigate effectiveness of levees to reduce flood inundation depth and area for the present and future climates.

In this study, we apply the BTOP and FID models for flood hazard assessment in Bangladesh under the present and future climates. Firstly, we utilize existing $20 \mathrm{~km}$ BTOP model with available WATCH Forcing Data (WFD) for the GBM basin (Weedon et al., 2011) and calibrate the BTOP model with the Bangladesh observed river discharge data (BWDB, 2014). Secondly, the calibrated BTOP model is applied with the forcing data of the Meteorological Research Institute atmospheric general circulation model (MRI-AGCM) 3.2S for the present and future climates for the SRES A1B scenario (Mizuta et al., 2012). The simulated BTOP discharges are utilized for the flood frequency analysis to produce flood peak discharges of 10-, 25-, 50- and 100-year return period. Next, the FID model is used in the Bangladesh portion of the GBM basin to produce flood water levels and inundation area considering height of levees in Bangladesh (BWDB, 2014). Finally, the potential flood inundation depth and area maps of 50- and 100-year flood peak discharges are compared for the present and future climates and used to estimate flood risks in Part 2 of this study.

\section{Study area}

In this study, we selected the entire GBM basin to simulate river discharge and only the Bangladesh portion of the GBM basin for the flood inundation simulations. In Fig. 1a, the GBM basin has a total drainage area of $1712700 \mathrm{~km}^{2}$ that consists of $1087300 \mathrm{~km}^{2}$ for the Ganges River, $543400 \mathrm{~km}^{2}$ for the Brahmaputra River and $82000 \mathrm{~km}^{2}$ for the Meghna River (FAO, 2012). The GBM basin is located in India, China, Bhutan, Nepal, and Bangladesh and has a wide range of climatic conditions from high altitude at the Himalayan and Vindhya ranges to low elevation areas at the Bay of Bengal (FAO, 2012). In Bangladesh, the Ganges and Brahmaputra rivers confluence at the Padma River and the Meghna River, which originates in the north-east of Bangladesh, joins the Padma River near the mouth of the GBM basin (Fig. 1b). FAO (2012) reports that the Bangladesh portion of the GBM basin has an area of $120400 \mathrm{~km}^{2}$ with $46300 \mathrm{~km}^{2}$ of the Ganges basin, $39100 \mathrm{~km}^{2}$ of the Brahmaputra basin and $35000 \mathrm{~km}^{2}$ of the Meghna basin (Fig. 1b). In northern part of Bangladesh, four flood prone administrative districts with an area of $8008 \mathrm{~km}^{2}$ are located in the Bangladesh portion of the Brahmaputra basin (see Fig. 1c).

For the Bangladesh data, the Hydrology Division of the Bangladesh Water Development Board (BWDB) measures river water levels 5 times per day at observation gauging stations (see Fig. 1b). In BWDB, these observed water levels are converted to daily river discharges using rating curves (IWM, 2006) constructed for the four gauging stations (Fig. 1b). In addition, BWDB measures river discharges weekly by the velocity-area method at four river gauging stations (BWDB, 2014). For the Goalondo station, the river discharge is con- 
sidered as a sum of the Ganges and Brahmaputra discharges in this study due to lack of the river water level and discharge observation data during the flood season. For the flood water levels, BWDB distinguishes between rivers with and without an embankment. In an embanked river, BWDB selects the danger water level (DWL) above which flood inundation occurs to be below a design flood level of the embankment while a river channel without embankment has DWLs equal to the annual average flood water level (BWDB, 2014).

\section{Methodology}

\subsection{Flood hazard assessment}

In our flood hazard methodology, we simulate flood peak discharges (Step 1) and flood inundation depth maps with river embankments (Step 2) to quantify the effectiveness the existing infrastructure under climate change (Fig. 2). For the flood discharge step, the existing $20 \mathrm{~km}$ BTOP model, which is developed from global data sets and utilized for discharge generation globally, is run with daily forcing data and is calibrated with the daily available discharge data at river gauging stations. From the river discharges simulated with the calibrated model, the flood peaks of the selected return periods such as 10-, 25-, 50- and 100-year are estimated with the flood frequency analysis and compared to the historical observations. For the climate change impacts, the calibrated $20 \mathrm{~km}$ BTOP model is run with General Circulation Model daily forcing data for the present (1979-2003) and future (2075-2099) climates to generate river discharges, which are utilized in the flood frequency analysis.

In the flood inundation step, the $0.45 \mathrm{~km}$ FID model, which is constructed using globally available data sets, estimates flood water levels considering height of river embankments from flood peak discharges estimated in step 1 and produces potential flood inundation area and depth maps. In the FID model, flood water levels are generated using synthetic rating curves and are calibrated with measured river flood water level and river cross-section data. The potential inundation maps simulated with the FID model are compared with the available record of historical inundation area and depth maps. For the climate change impact assessment, the change of potential flood inundation depth between present and future climates is demonstrated to evaluate the effectiveness of existing river infrastructure in the future.

\section{$3.220 \mathrm{~km}$ BTOP model in the GBM basin}

For the discharge simulations in the GBM basin, we utilized the $20 \mathrm{~km}$ BTOP model, which was developed from the globally available datasets for the global river discharge generation. The BTOP model is a distributed hydrological model that uses a modified topographical index to simulate rainfall-runoff processes including snowmelt, overland flow, soil moisture in the root and unsaturated zones, sub-

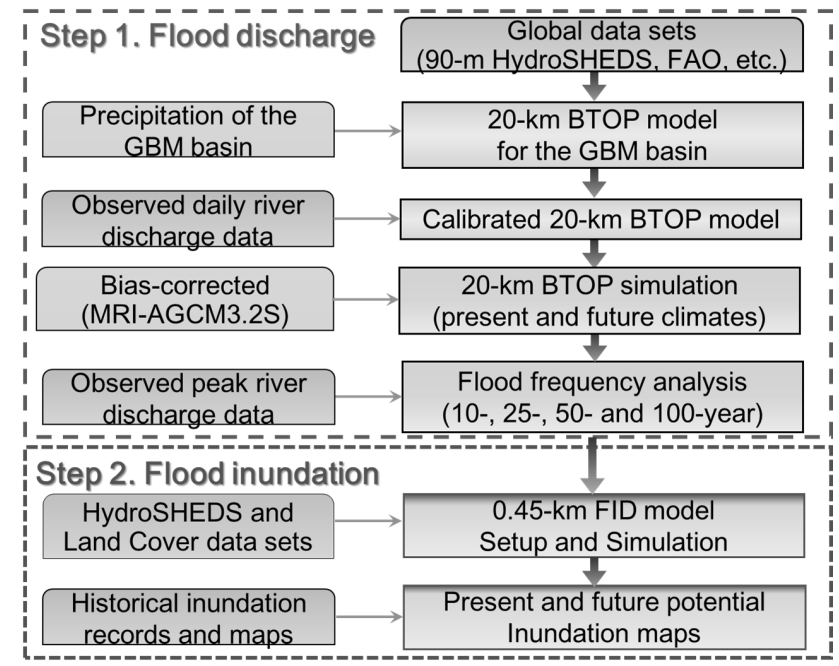

Figure 2. Flood hazard assessment methodology implemented in our study.

surface flow, and river flow routing (Takeuchi et al., 2008). The $20 \mathrm{~km}$ BTOP model was constructed from $90 \mathrm{~m}$ HydroSHEDS Digital Elevation Model (DEM) (Lehner et al., 2008) using river network upscaling algorithm (Masutani and Magome, 2008). From the existing $20 \mathrm{~km}$ BTOP model, we introduced four blocks with the outlets at the four river gauging stations in Bangladesh to represent the Ganges, Brahmaputra, Meghna and Padma river basins by each BTOP model block (Takeuchi et al., 2008).

In this study, we utilized WFD and MRI-AGCM3.2S (SRES A1B scenario) forcing data sets with daily values on $20 \mathrm{~km}$ resolution in the GBM basin. For the WFD data set, we selected a range between 1980 and 2001 of the WFD daily precipitation and temperature data developed by Weedon et al. (2011) to match available river discharge data in Bangladesh (BWDB, 2014). For the MRI-AGCM3.2S data set, the daily precipitation data were used for the present (1979-2003) and future (2075-2099) climates (Mizuta et al., 2012). For the MRI-AGCM3.2S precipitation, we applied a bias-correction factor, which was estimated as each sub-basin averaged long term (22 years) monthly mean rainfall of the WFD data (Masood et al., 2015). The long term seasonal potential evapotranspiration (PET) within BTOP model was estimated by the Shuttleworth-Wallace (SW) model using climate forcing data Climatic Research Unit (CRU) TS3.1 (UEA CRU, 2008) and a fortnightly Normalized Difference Vegetation Index (NDVI) (Tucker et al., 1994).

The BTOP model performance was evaluated with NashSutcliffe efficiency (NSE) (Nash and Sutcliffe, 1970) and correlation coefficient (CC) for the calibration period of 1981-1990 and the validation period of 1991-2000. To estimate flood peak discharges beyond the existing record, we applied flood frequency analysis using L-moment ratio dia- 


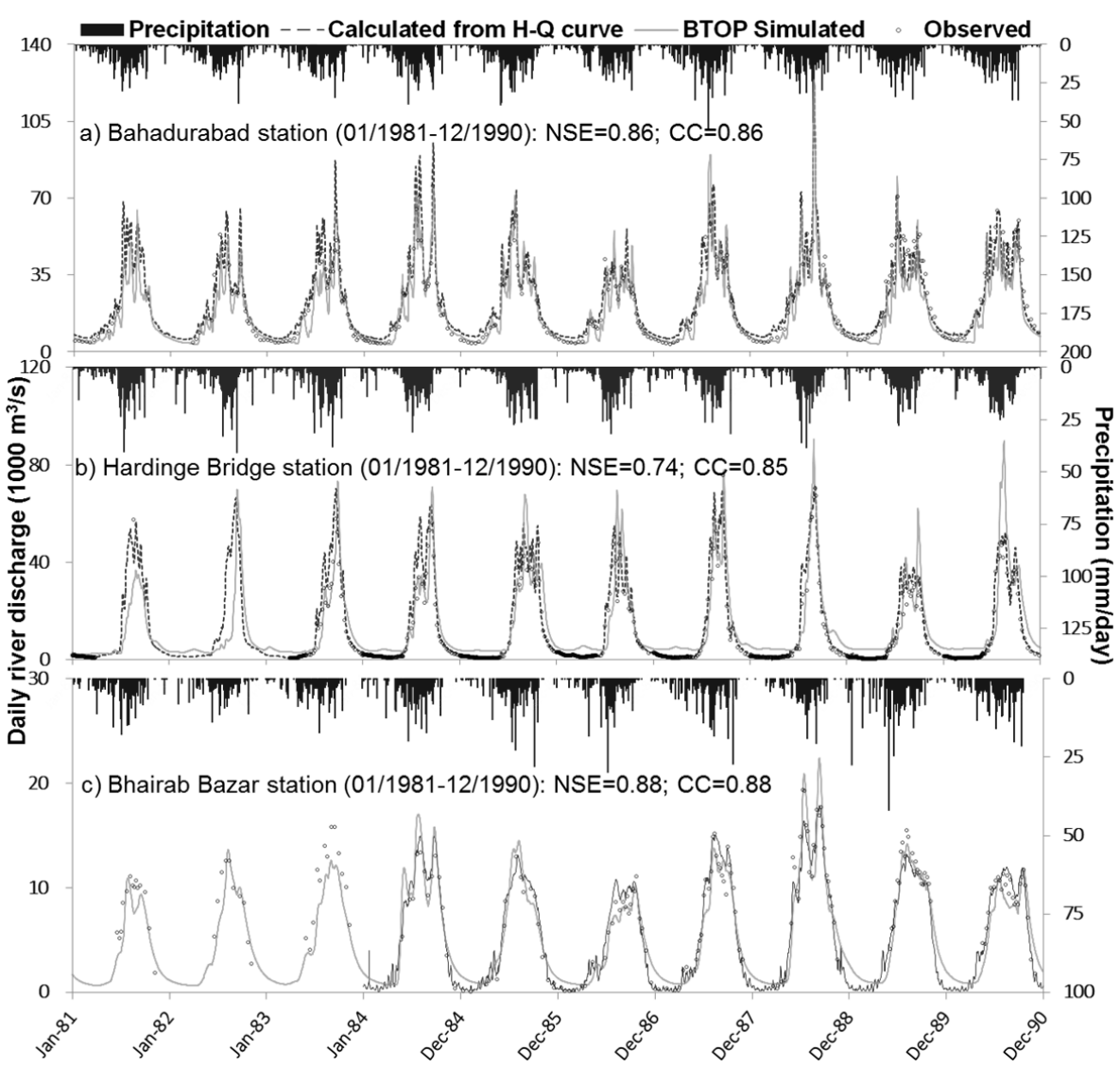

Figure 3. Daily river discharges for the BTOP model calibration at Bahadurabad (a), Hardinge Bridge (b), and Bhairab Bazar (c) stations.

gram with the Gumbel distribution to obtain 10-, 25-, 50- and 100-year return period flood peak discharges.

\subsection{FID model in Bangladesh}

In the Bangladesh portion of the GBM basin, the $0.45 \mathrm{~km}$ FID model simulated the flood water level and estimated potential flood inundation depth and area using flood peak discharges of a selected return period produced at each BTOP grid (Kwak et al., 2012). The FID model is a GIS-based model developed from about $0.5 \mathrm{~km}$ HydroSHEDS data set (Lehner et al., 2008) and converts flood peak discharges to flood river water levels using a synthetic rating curve developed with Manning's equation (Kwak et al., 2012). The FID simulated flood water levels of the 10-year return period discharge were considered as DWLs, which include height of embankments. The FID simulated flood water levels of the 50-year return period were calibrated with the recorded highest water level (RHWL) data selected at the 40 gauging stations in the study area (Fig. 1b). In addition, these flood peak water levels of the 50-year return period were verified with three cross-sections of the Brahmaputra River (Fig. 1c). From the optimized FID flood water levels, the potential flood inundation maps produced with 25- and 100-year flood peak discharges were compared with the MODIS images of 2004 Bangladesh flood and the historical flooded district area of 1998 Bangladesh flood, respectively (BWDB, 2014). For the climate change impacts, we analyzed the change of potential flood inundation depth between future and present climates.

\section{Results and discussion}

\subsection{Simulated flood discharges in the GBM basin}

The BTOP simulated river discharges with WFD forcing data are shown in Fig. 3 for the calibration period (1981-1990) and for the validation period (1991-2000) in Fig. 4. In both figures, the BWDB measured river discharges are shown by circle and discharges calculated based on the rating curves by dashed line. The BTOP river discharge simulations are found in good statistical agreement with the historical discharges at four stations, see demonstrated statistics in Figs. 3 and 4 (Goalondo station is not shown). For the Goalondo station, the BTOP simulated discharges follow a combined influence of the Ganges and Brahmaputra Rivers and the NSE equals to 0.88 for the calibration period and to 0.86 for the validation period. In the BTOP model, the Farakka barrage operation, 


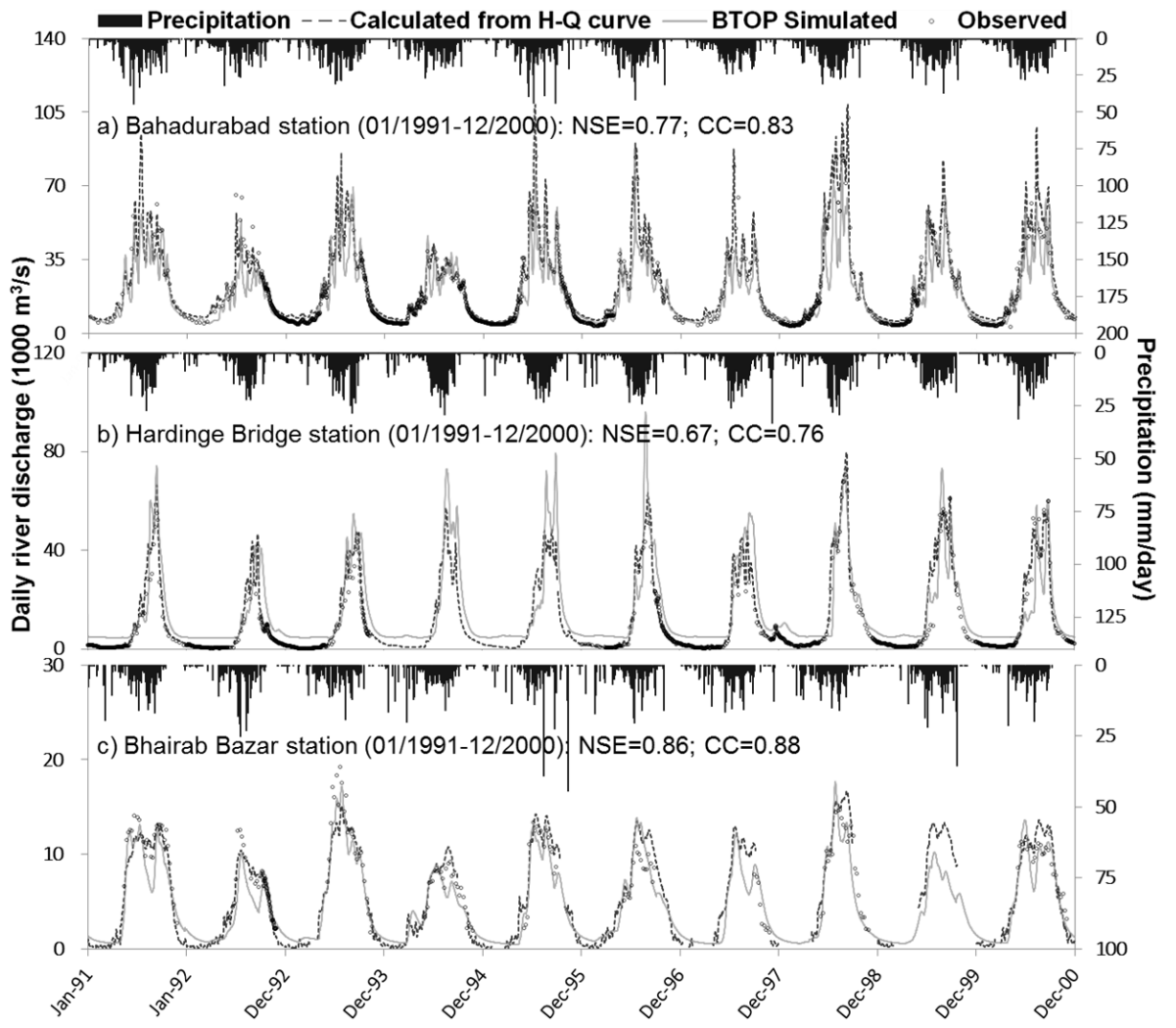

Figure 4. Daily river discharges for the BTOP model validation at Bahadurabad (a), Hardinge Bridge (b), and Bhairab Bazar (c) stations.

which is located near Bangladesh border and diverts Ganges river water for irrigation in India during dry season, was not considered and may be attributed to the overestimation of the low flows (FAO, 2012). For the historical flood peak discharges, the 1988 and 1998 floods are considered 50- and 100-year return period floods, respectively (BWDB, 2014). These historical discharges are comparable to the flood peak discharges estimated with the flood frequency analysis and simulated BTOP discharges in Figs. 3 and 4. The 50-year return period flood peak discharges are about $104000 \mathrm{cms}$ at the Hardinge Bridge station and about $86000 \mathrm{cms}$ at the Bahadurabad station. For the 100-year return period, the flood discharges are $110000 \mathrm{cms}$ at the Hardinge Bridge station and $92000 \mathrm{cms}$ at the Bahadurabad station. For the Goalondo station, the BTOP simulated river discharges are about $205000 \mathrm{cms}$ in 1988 and about $215000 \mathrm{cms}$ in 1998 . For the climate change impact analysis, the simulated BTOP discharges for present and future climates with the biascorrected MRI-AGCM3.2S forcing data demonstrate an increasing trend of the flood peak discharges at all stations. For example, both 50- and 100-year flood peak discharges of the future climates increased by about 2.1 times at the Bahadurabad station, by about 1.4 times at the Hardinge Bridge station and by about 1.7 times at the Bhairab Bazar station.

\subsection{Simulated flood inundation in Bangladesh}

In Bangladesh, historical flood inundation maps are not available to make a direct comparison between simulated and actual flood inundation depth (BWDB, 2014). For the flood water level calibration, the FID flood water levels of the 50 -year peak discharge shows a good correlation with the RHWL data $\left(R^{2}=0.79\right)$ and are used to produce potential flood inundation maps. For the 25-year return period flood, the FID model map resulted in inundated area of $41523 \mathrm{~km}^{2}$ (Fig. 5a) and is considered to represent the 2004 flood in Bangladesh with the inundation area of $40704 \mathrm{~km}^{2}$ (BWDB, 2014). In Fig. 5b, the 2004 flood inundation area is verified by the 8-day composite of Terra sensor MODIS satellite image collected for 27 July 2004-3 August 2004 (EOS, 2006) and has inundation area of about $40000 \mathrm{~km}^{2}$ detected from the MODIS satellite image. The potential inundation map of the 50-year flood discharge indicates an inundation area of $47600 \mathrm{~km}^{2}(35.9 \%)$ and the 1988 flood inundated $61 \%$ of Bangladesh (BWDB, 2014). For the 100-year flood, the potential inundation area produced with the FID model covered an area of $52149 \mathrm{~km}^{2}$ (43.4\%) while the historical 1998 flood inundated $68 \%$ of Bangladesh based on district level information (BWDB, 2014).

For the climate change impact assessment, the change of the flood inundation depth is presented in Fig. $5 \mathrm{c}$ for the 50- 


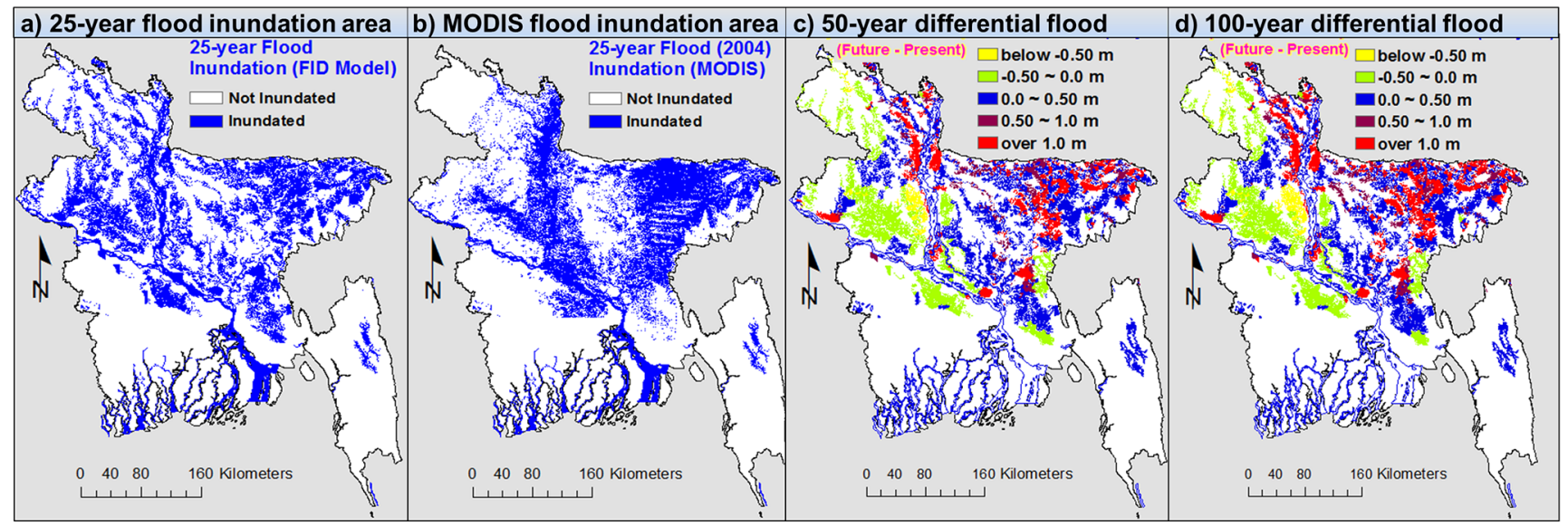

Figure 5. The 25-year flood inundation area produced with FID model (a) and MODIS image (b) data. The change between future and present flood inundation depth for 50-year flood (c) and 100-year flood (d) with existing levee infrastructure.

year flood and for the 100-year flood in Fig. 5d. In Fig. 5c, the potential flood inundation area increases by $2639 \mathrm{~km}^{2}$ from $47600 \mathrm{~km}^{2}$ in the present to $50239 \mathrm{~km}^{2}$ in the future for the 50 -year flood and by $2518 \mathrm{~km}^{2}$ from $52149 \mathrm{~km}^{2}$ in the present to $54667 \mathrm{~km}^{2}$ in the future for the 100 -year flood in Fig. 5d. However, the spatial distribution of flood depth change in the Bangladesh potion of the GBM basin is not uniform with a decreasing trend for the Ganges and Padma basins and an increasing trend for the Brahmaputra and Meghna basins. For the 50-year flood, the flood inundation area of $33151 \mathrm{~km}^{2}$ has an increase of flood inundation depth by more than $50 \mathrm{~cm}$ in the area of $12929 \mathrm{~km}^{2}$ and by more than $100 \mathrm{~cm}-8951 \mathrm{~km}^{2}$ between future and present climates. For the 100-year flood, the flood inundation area of $39040 \mathrm{~km}^{2}$ has an increase of flood inundation depth by more than $50 \mathrm{~cm}$ in the area of $17568 \mathrm{~km}^{2}$ and by more than $100 \mathrm{~cm}-12883 \mathrm{~km}^{2}$. These preliminary inundation area and depth maps indicate potential flood hazard hotspots in the Bangladesh portion of the Brahmaputa and the Meghna river basins, where height of the existing embankment may be insufficient to reduce the future flood hazard.

\section{Concluding remarks}

In this study, the $0.45 \mathrm{~km}$ FID model was developed in the Bangladesh portion of the GBM basin to produce flood inundation maps using simulated river discharges with the $20 \mathrm{~km}$ BTOP model applied for the entire GBM basin. In the GBM basin, the $20 \mathrm{~km}$ BTOP model was run with WFD forcing data from 1980 to 2000 and with bias-corrected MRI-AGCM3.2S for the present (1979-2003) and future (2075-2099) climates. The BTOP model with WFD forcing data was calibrated with river discharge data at four stations in Bangladesh and represented river flows in the GBM basin. For the flood frequency analysis, the Gumbel distribution with L-moments was selected to produce 10-, 25-,
50- and 100-year return period flood discharges from simulated BTOP discharges for the present and future climates. For the climate change impacts, the magnitude of the flood discharges increases under the future climates in Bangladesh area. For 50- and 100-year the flood peak discharges, the future discharge increased by about 2.1 times at the $\mathrm{Ba}$ hadurabad station, by about 1.4 times at the Hardinge Bridge station and by about 1.7 times at the Bhairab Bazar station.

The potential flood inundation maps were produced with the FID model for the Bangladesh portion of the GBM basin. For the past Bangladesh floods, historical flood inundation maps are not available for the detailed comparison of inundation extent and depth. The total inundation area of 100-year historical flood reported by BWDB (2014) was comparable to the inundation areas simulated with the FID model. For the 25-year flood inundation map, the 2004 flood inundation area of the MODIS image and of the BWDB (2014) historical data was similar to the potential flood inundation maps simulated with the FID model. For the climate change impacts, the potential flood inundation area increases by $4.83 \%$ for the 50 -year flood and by $5.54 \%$ from present to future for the 100-year flood. In both cases, the spatial distribution of flood depth change had a similar pattern: increased near the Brahmaputa and Meghna rivers and decreased near the Ganges and Padma rivers. These preliminary inundation area and depth maps indicate potential flood hazard hotspots, where height of the existing embankment may be insufficient to reduce the future flood hazard. In Part 2 of this study, we utilize these potential flood inundation hotspots to produce flood risk in terms of affected people and agricultural damages. The results of this study provide essential flood hazard and risk information to implement the Integrated Flood Management concept in Bangladesh. 
Acknowledgements. This research is supported by Public Works Research Institute (PWRI) and these results contribute to the International Flood Initiative (IFI) activities. We thank Mohammed Masood for his technical support of this study and Yoko Hagiwara for her editorial comments on the manuscript.

\section{References}

BWDB - Bangladesh Water Development Board: Observed river data and reports of 1988, 1998, and 2004 floods, http://www. bwdb.gov.bd, last access: August 2014.

EOS - Earth Observing System Data Gateway: NASA earth observing system data gateway, http://edcimswww.cr.usgs.gov/pub/ imswelcome (last access: July 2014), 2006.

FAO - Food and Agriculture Organization of the United Nations: Irrigation in Southern and Eastern Asia in Figures, AQUASTAT Survey-2011, FAO Water Report \#37, Rome, 2012.

IWM - Institute of Water Modelling: Updating and Validation of North West Region Model, Institute of Water Modelling, Bangladesh, 2006.

Johnston, R. and Smakhtin, V.: Hydrological Modeling of Large river Basins: How Much is Enough?, Water Resour. Manage., 28, 2695-2730, 2014.

Kwak, Y., Takeuchi, K., Fukami, K., and Magome, J.: A new approach to flood risk assessment in Asia-Pacific region based on MRI-AGCM outputs, Hydrol. Res. Lett., 6, 70-75, doi:10.3178/HRL.6.70, 2012.

Lehner, B., Verdin, K., and Jarvis, A.: New global hydrography derived from spaceborne elevation data, EOS Trans. AGU, 89, $93-$ 94, 2008.

Masood, M., Yeh, P. J.-F., Hanasaki, N., and Takeuchi, K.: Model study of the impacts of future climate change on the hydrology of Ganges-Brahmaputra-Meghna basin, Hydrol. Earth Syst. Sci., 19, 747-770, doi:10.5194/hess-19-747-2015, 2015.
Masutani, K. and Magome, J.: Effects of the Novel Scaling Algorithm on River Networks on Discharge Simulations, J. Jpn. Soc. Hydrol. Water Res., 21, 242-247, 2008.

Mizuta, R., Yoshimura, H., Murakami, H., Matsueda, M., Endo, H., Ose, T., Kamiguchi, K., Hosaka, M., Sugi, M., Yukimoto, S., Kusunoki, S., and Kitoh, A.: Climate Simulations Using MRIAGCM3.2 with 20-km Grid, J. Meteorol. Soc. Jpn., 90, 233-258, doi:10.2151/jmsj.2012-A12, 2012.

Nash, J. E. and Sutcliffe, J. V.: River flow forecasting through conceptual models Part I - A discussion of principles, J. Hydrol., 10, 282-290, 1970.

Takeuchi, K., Hapuarachchi, P., Zhou, M., Ishidaira, H., and Magome, J.: A BTOP model to extend TOPMODEL for distributed hydrological simulation of large basins, Hydrol. Process., 22, 3236-3251, doi:10.1002/hyp.6910, 2008.

Tucker, C. J., Pinzon, J. E., and Brown, M. E.: Global Inventory Modeling and Mapping Studies, NA94apr15b.n11-VIg, 2.0, Global Land Cover Facility, University of Maryland, College Park, 1994.

UEA CRU - University of East Anglia Climatic Research Unit: CRU Time Series (TS) high resolution gridded datasets, edited by: Jones, P. and Harris, I., NCAS British Atmospheric Data Centre, Norwich, 2008.

Weedon, G. P., Gomes, S., Viterbo, P., Shuttleworth, W. J., Blyth, E., Osterle, H., Adam, J. C., Bellouin, N., Boucher, O., and Best, M.: Creation of the WATCH Forcing Data and its use to assess global and regional reference crop evaporation over land during the twentieth century, J. Hydrometeorol., 12, 823-848, 2011.

Winsemius, H. C., Van Beek, L. P. H., Jongman, B., Ward, P. J., and Bouwman, A.: A framework for global river flood risk assessments, Hydrol. Earth Syst. Sci., 17, 1871-1892, doi:10.5194/hess-17-1871-2013, 2013. 